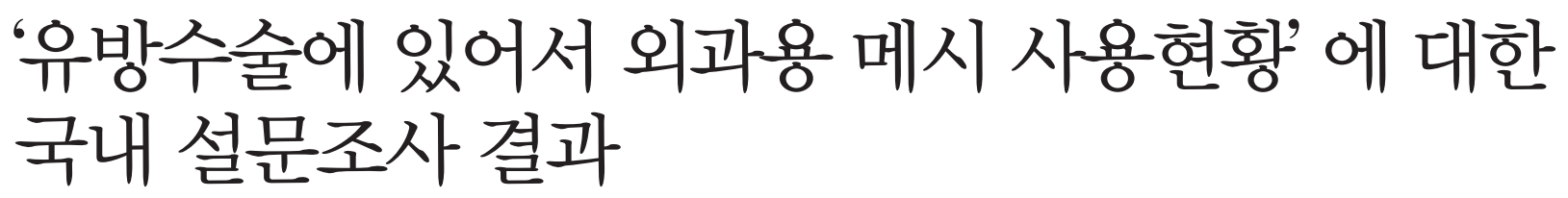

김구상 ${ }^{1,2}$ - 박만영 ${ }^{2}$. 김우재 ${ }^{2} \cdot$ 나국영 $^{1}$ - 정용식 ${ }^{1}$ - 최영진 ${ }^{3}$ - 박용래 ${ }^{4} \cdot$ 오세정 ${ }^{5}$ - 신혁재 ${ }^{6}$ - 한국유방암학회

${ }^{1}$ 아주대학교 의과대학 외과학교실 · ${ }^{2}$ 의료정보학교실, ${ }^{3}$ 을지대학교 의과대학 외과학교실,

${ }^{4}$ 성균관대학교 의과대학 강북삼성병원 외과학교실, ${ }^{5}$ 가톨릭대학교 의과대학 외과학교실, ${ }^{6}$ 관동대학교 의과대학 외과학교실, 한국유방암학회

\title{
Nationwide Survey of the Use of Absorbable Mesh in Breast Surgery in Korea
}

Ku Sang Kim ${ }^{1,2}$, Man Young Park², Woo Jae Kim², Kuk Young Na ${ }^{1}$, Yong Sik Jung ${ }^{1}$, Young Jin Choi ${ }^{3}$, Yong Lai Park Se-Jeong $\mathrm{Oh}^{5}$, Hyuk-Jae Shin ${ }^{6}$, Korean Breast Cancer Society

Departments of ' Surgery and ${ }^{2}$ Medical Informatics, Ajou University School of Medicine, Suwon; ${ }^{3}$ Department of Surgery, Eulji University College of Medicine, Daejeon; ' $D$ Department of Surgery, Kangbuk Samsung Hospital, Sungkyunkwan University School of Medicine, Seoul; ${ }^{5}$ Department of Surgery, the Catholic University College of Medicine, Seoul; ${ }^{6}$ Department of Surgery, Kwandong University School of Medicine, Goyang; Korean Breast Cancer Society, Seoul, Korea

The aim of this study is to investigate the use of absorbable mesh in breast surgery in Korea. We conducted a survey from members of Korea Breast Cancer Society by phone, E-mail, and notice on the website from 6th to 20th April 2009. A total of 54 breast surgeons had responded to the survey. Of these, 40 surgeons $(74.1 \%)$ had used absorbable mesh during breast surgery, with Vicryl mesh ${ }^{\circledast}$ being the choice of every surgeon and Interceed ${ }^{\circledR}$ having been used by $36(90 \%)$ of the surgeons. In responding to the indications for mesh use, 26 surgeons (65\%) indicated that mesh use was effective when a deformity was expected regardless of T stage. Contraindications for mesh use principally included existing patients' comorbidity such as a wound healing problem, diabetes mellitus and immunocompromised condition. Thirty one surgeons $(77.5 \%)$ had experienced an infection in the mesh insertion site. However, on a case basis, only 39 of 843 cases
(4.6\%) had resulted in an infection. In the follow up after mesh use, 33 of the 37 responding surgeons (89.2\%) used breast ultrasonography. Nineteen of the 38 respondents $(50 \%)$ replied that the mesh was absorbed in 6 months and it did not confuse diagnostic imaging. The cited merits of mesh included maintenance of breast shape following surgery $(n=$ $38 / 49,77.6 \%)$ and ease of surgical use ( $n=35 / 49,71.4 \%)$. However, the high price of mesh was cited as a disadvantage by 33 of the 48 respondents (68.8\%). In summary, survey results mentioned above show that surgical mesh use in breast surgery is increasing by times and the procedures greatly varies by surgeons. Thereby, we suggest that a guideline for mesh use should be made in the near future.

Key Words: Breast, Surgery, Surgical mesh 중심단어: 유방, 수술, 외과용 메시

\section{책임저자: 신혁재}

412-270 경기도 고양시 덕양구 관동대학교 명지병원 외과

Tel: 031-810-6890, Fax: 031-969-0500

E-mail: drgss@chol.com

접수일: 2009년 6월 29일 게재승인일: 2009년 8월 28일

본 연구는 2009 년 5 월 한국유방암학회 유방외과술기연구회 심포지엄에서 구연 발표되었음.

본 연구는 2009년 7월 한국유방암학회 경기인천지회 국제심포지엄에서 구 연 발표되었음.

\section{서 론}

최근의 한국 유방암학회 등록자료에 의하면 유방암의 증가와 함께 조기유방암의 비율이 증가하고 있으며, 이에 따라 유방보존 술(breast conserving surgery)이 지속적으로 증가하여 유방 암 수술의 약 $50 \%$ 를 차지하게 되었다. (1,2) 유방보존술이 변형근 치유방절제술(modified radical mastectomy)만큼의 종양학적 
안정성과 미용적인 우수성이 입증되었지만, 유방이 작은 경우나 종양의 크기와 위치에 따라서는 충분한 미용적인 효과를 얻기 어 려울 수 있다. $(3,4)$ 이러한 문제점을 극복하기 위하여, 종양성형 적 수술(oncoplastic surgery)의 필요성이 대두되어 남은 유방 조직을 이동시키거나 광배근(latissimus dorsi muscle) 피판 등의 주변조직을 이용하여 미용적인 효과와 종양학적인 안전성 을 동시에 확보하려는 노력이 우수한 성적을 내고 있다. (5-7) 그 러나 이러한 종양성형적 수술은 좀 더 넓은 범위의 절제를 할 수 있다는 장점도 있지만, 상대적으로 많은 수술시간이 필요하며, 한국인과 같이 작은 유방에서는 적용 폭이 좁다는 단점이 있어, 외과용 메시(surgical mesh)를 이용한 간단한 술기로 수술시간 을 단축시키며, 작은 결손 부위를 효과적으로 채울 수 있는 방법 이 소개되었으며, (8) 국내의 많은 시술자가 유방수술에 있어서 메 시를 사용하고 있는 것으로 알려져 있다. $(4,9)$ 그러나 메시를 이 용한 술기에 있어서 각자의 적응증, 사용방법, 관리방법이나 합 병증에 대해서는 서로 공유하는 정보나 표준화된 지침이 없는 실 정으로 국내의 메시 사용현황을 파악하고자 하였다.

\section{조사 방법}

2009년 4월 6일부터 20일까지 한국유방암학회 회원을 대상으 로 이메일(E-mail)과 학회 홈페이지의 공지란을 통하여 인터넷 상에서 설문조사를 진행하였으며, 필요한 경우엔 전화연락도 병 행하여 설문조사를 진행하였다. 설문의 내용은 설문 대상자의 일 반적 특성이 9문항, 메시 사용현황에 대한 설문이 8문항, 메시 사 용방법이 12 문항, 메시 사용에 따른 합병증이 12 문항, 메시 사용 후의 추적관찰이 3 문항, 메시 사용의 장단점이 2 문항, 메시 적용 지침의 개발관련 문항이 모두 2 개로 총 48 문항으로 이루어 졌다. 답변은 다시 세분화하여 SPSS statistical software system

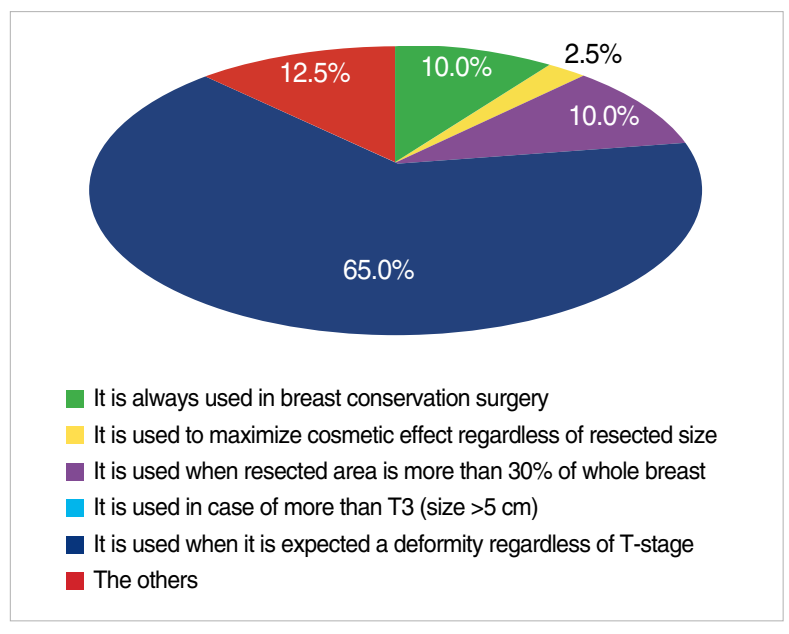

Figure 1. Indications of absorbable mesh. (version 15.0K; SPSS Inc., Chicago, USA) 통계프로그램을 이용하여 빈도 분석하였다.

\section{응답자의 일반적 특성}

총 54 명의 유방외과 전문의가 응답했고, 남녀비는 $85.2 \%$ ( $\mathrm{n}=$ $46) / 14.3 \%(n=8)$ 였으며, 연령대는 30 대가 $46.3 \%(n=25), 40$ 대 가 $33.3 \%(n=18), 50$ 대가 $16.7 \%(n=9)$ 였으며, 지역별로는 서울 과 경기도가 $61.1 \%(n=33)$ 를 차지하고, 나머지는 전국에 고른 분 포를 보였다. 대학병원이 $75.9 \%(\mathrm{n}=41)$ 였으며, 암 전문 병원과 종 합병원 외에도 유방클리닉과 준 종합병원에서도 설문조사에 참가 하였다. 각 병원의 유방암 수술건수도 100 건 이하가 $42.6 \%$ (n= $23), 101$ 건 이상에서 200 건 이하가 $26.4 \%(n=14), 201$ 건 이상 에서 500 건 이하가 $17 \%(n=9), 501$ 건 이상에서 1,000 건 이하가 $5.7 \%(\mathrm{n}=3), 1,001$ 건 이상도 $7.5 \%(\mathrm{n}=4)$ 로 고른 분포를 보였다.

\section{메시 사용 현황 및 사용 방법}

전체 응답자 중 $74.1 \%(n=40)$ 가 메시를 사용한 경험이 있었으 며, 모두 Polyglatin 910재질로 만들어진 Vicryl Mesh ${ }^{\circledR}$ (Ethicon, Johnson and Johnson, Somerville, USA)를 사용하였다. 지 난 1 년간 메시를 사용한 증례 수는 5건 이하가 $22.5 \%$ (n=9), 6건 이상에서 10 건 이하가 $22.5 \%(n=9), 11$ 건 이상에서 30 건 이하가 $27.5 \%$ ( $\mathrm{n}=11), 31$ 건 이상에서 50 건 이하가 $12.5 \%(\mathrm{n}=5), 51$ 건 이상도 $15 \%(n=6)$ 로 조사되었으며, $90 \%(n=36)$ 의 응답자가 항 상 oxidized regenerated cellulose로 만들어진 Interceed ${ }^{\circledR}$ (Ethicon, Johnson and Johnson, Somerville, USA)를 같이 사용하였다. 메시 사용의 적응증으로는 $65 \%(n=26)$ 가 T 병기에 상관없이 절제된 부위가 넓어 유방 형태의 변형이 예상되는 경우 에 사용한다고 했으며, 나머지는 여러 가지의 고른 적응증을 나타 냈다(Figure 1). 동반질환이 있는 경우에는 특히, 상처치유에 문

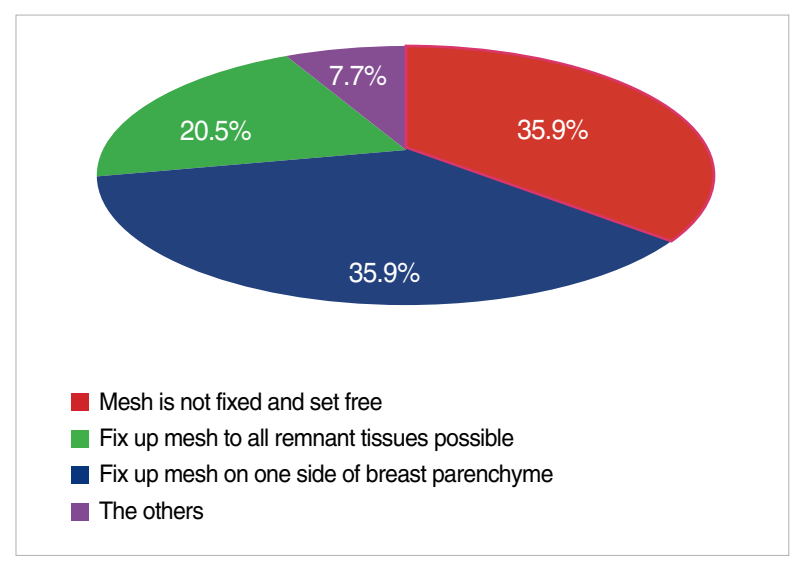

Figure 2. Methods of application of absorbable mesh. 
제가 있는 환자에게는 사용하지 않는다는 응답이 $80 \%(\mathrm{n}=32)$ 로 가장 많은 비율을 차지했고, 면역력이 저하된 환자에게는 사용하 지 않는 경우와 당뇨가 있는 환자에게는 사용하지 않는 경우가 $62.5 \%$ ( $\mathrm{n}=25$ )와 $52.5 \%$ ( $\mathrm{n}=21$ )의 분포를 보였다. 메시의 형태를 부채꼴 모양으로 접어서 사용한다는 응답이 $87.5 \%(\mathrm{n}=35)$ 로써 가 장 많았고, 고정 방법으로는 고정하지 않고 결손 부위(defect)에 자유롭게 위치시키는 경우와 유방 실질 한쪽에만 고정하는 경우 가 모두 $35.9(\mathrm{n}=14 / 39)$ 로 나타났다(Figure 2). Interceed ${ }^{\circledR}$ 는 $86.5 \%$ ( $n=32 / 37)$ 의 응답자가 메시 전체를 싸서 사용하고 있고, 결손 범위가 넓을 경우에도 메시를 한 개만 사용하는 경우가 $67.5 \%$ $(n=27 / 40)$, 경우에 따라 두 개 혹은 세 개를 사용하는 경우가 $27.5 \%$ $(n=11 / 40)$ 를 차지했다. 메시를 삽입할 경우 결손 부위에 대해서는 $52.5 \%$ ( $n=21)$ 의 응답자가 특별한 조치를 하지 않는다고 답했으며, $27.5 \%$ ( $\mathrm{n}=11)$ 는 생리 식염수로 세척한다고 답하였다. 상처 봉합 시에 $40 \%(n=16)$ 의 응답자가 통상적인 방법으로 봉합하며, 주변 지방조직을 이용하여 피부와 절제부위 간에 차벽을 만들어 준다 는 경우와 피부 밑의 피부 하 조직을 최대한 두껍게 봉합하는 경 우가 각각 $32.5 \%(\mathrm{n}=13)$ 와 $25 \%(\mathrm{n}=10)$ 로 나타났다. 메시가 있 는 상태에서 배액관의 거치 여부에 대해서는 메시가 있다면 범위

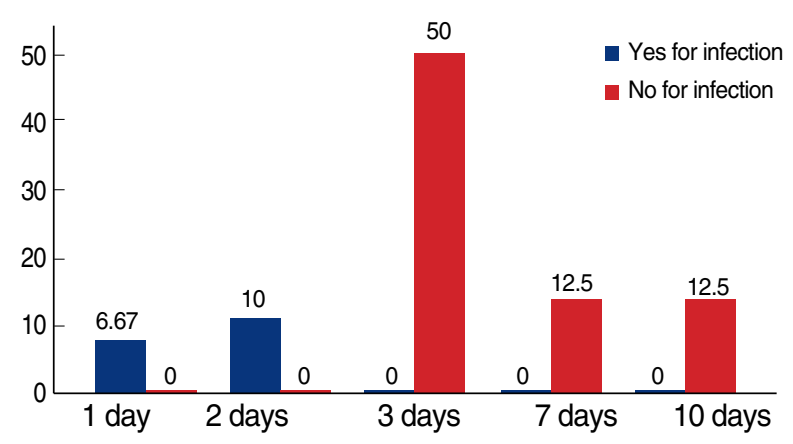

Figure 3. Duration of use of prophylactic antibiotics.

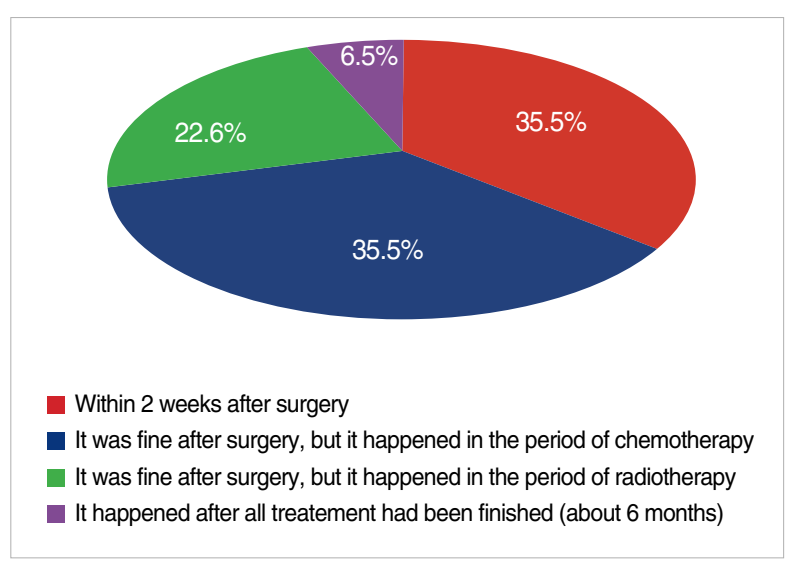

Figure 4. Infection time of absorbable mesh.
가 넓어도 배액관을 거치하지 않는다는 응답이 $84.6 \%(n=33)$ 로 가장 많았고, 메시 유무에 관계없이 배액관을 거치하지 않는다는 의견과 메시에 상관없이 범위가 넓다면 통상적으로 거치한다는 의견이 각각 $5 \%(n=2)$ 와 $10 \%(n=4)$ 를 나타냈다. 예방적 항생제 사용 여부에 관한 설문에는 $95 \%(n=38)$ 의 응답자가 사용한다고 답하였고, 사용 기간은 평균 5.2 일(표준편차는 4.5 일)이며, 최소 1 일에서 최대 21 일간 사용한 것으로 나타났다(Figure 3).

\section{메시 사용에 따른 합병증}

메시를 사용하면서 삽입 부위의 감염은 $77.5 \%(n=31)$ 의 응답 자가 경험하였으며, 총 시술건수로 보면 843건 중에 39건으로 $4.6 \%$ 를 차지했으며, 감염을 경험하지 않은 응답자의 시술건수까 지 평균값으로 예측해보면, 총 1,019 건 중에 39 건으로 약 $3.8 \%$ 로 볼 수 있었다. 감염된 경우에 환자가 가지고 있는 동반질환이 없는 경우가 69\% (n=20/29)를 차지했고, 당뇨인 경우가 $17.2 \%(\mathrm{n}=$ $5 / 29$ )를 차지했다. 감염된 시점에 관한 질문에서는 수술 후 2 주일 이내, 수술 후에는 괜찮았으나 항암치료 중 발생한 경우, 수술 후 에는 괜찮았으나 방사선치료 중 발생한 경우가 전체 31 명 중 각각 $35.5 \%(n=11), 35.5 \%(n=11), 22.6 \%(n=7)$ 로 메시의 감염은 다 양한 시기에 발생하는 것을 알 수 있었다(Figure 4). 감염이 되었 을 경우에는 $62.5 \%(n=19)$ 의 시술자가 메시를 제거하였다고 답하 였다. 삽입부위의 출혈은 응답자의 $11 \%(n=4)$ 만이 경험하였으며, 총 1,019 건 중에 7 건으로 약 $0.7 \%$ 였다. 결국 메시를 제거한 경우 는 1 예 있었다. 메시를 사용하면서 삽입부위의 장액종(seroma)이 더 잘 생기는 것 같다는 의견이 $69.7 \%(n=23)$ 로 나타났다.

\section{메시 사용 후의 추적 관찰}

수술 후 추적 관찰 중에 주로 쓰는 영상진단법에 대한 질문에는 $89.2 \%$ ( $\mathrm{n}=33 / 37)$ 의 응답자가 유방 초음파촬영이라고 답했고, 중 복응답으로 유방 X선 촬영(mammogram)이 $51.4 \%$ ( $\mathrm{n}=19 / 37)$ 를 차지하였다(Figure 5). 수술 후 추적 관찰 중에 시행한 유방 X

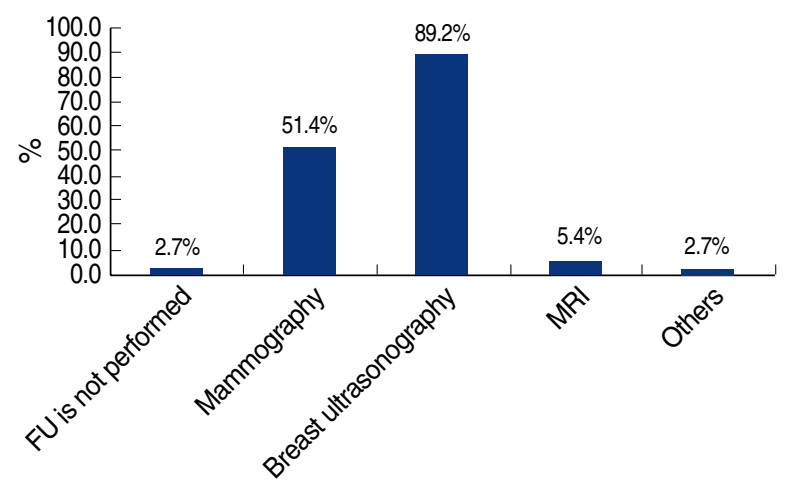

Figure 5. Follow up (FU) methods of absorbable mesh. 


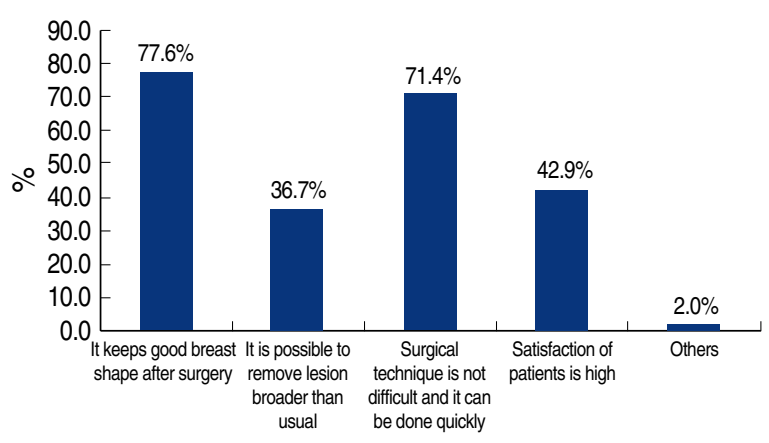

Figure 6. The advantage of absorbable mesh.

선 촬영, 초음파, 자기공명영상 촬영 등의 검사결과 판독에 $89.7 \%$ $(\mathrm{n}=35 / 39)$ 의 응답자는 의료진이 정보를 공유할 경우 혼란은 없 었다고 답하였고, 단지 $7.7 \%(\mathrm{n}=3 / 39)$ 만이 의료진이 정보를 공 유한 경우에도 혼란을 주는 경우가 있었다고 답하였다. 수술 후 어느 정도의 시간이 지나야 추적 관찰 중에 시행한 영상진단에 혼 란을 주지 않겠냐는 질문에는 50\% (n=19/38)의 시술자가 6개월 후면 흡수되어 문제가 되지 않았다고 답하였고, $28.9 \%(\mathrm{n}=11 / 38)$ 는 1 년이 지나야 한다고 답하였다. 시간이 지나도 계속 진단에 혼 란을 줄 것이라고 답한 응답자도 $10.5 \%(n=4 / 38)$ 를 차지했다.

\section{메시 사용의 장단점}

복수응답으로 시행된 설문에서 메시의 장점으로는 응답자의 $77.6 \%$ ( $n=38 / 49)$ 가 수술 후 유방 모양이 좋다고 답하였고, $71.4 \%$ ( $n=35 / 49)$ 는 술기가 어렵지 않고, 신속히 수행할 수 있다라고 답 하였다. 또한, $42.9 \%(n=21 / 49)$ 가 환자의 만족도가 높다라고 답 하였다(Figure 6). 단점으로는 가격이 비싸다라고 응답한 시술 자가 $68.8 \%(n=33 / 48)$, 감염, 출혈, 장액종 등의 합병증이 많았 다가 $47.9 \%(n=23 / 48)$, 시간이 지나면 모양이 나빠진다는 답변 이 $25 \%(n=12 / 48)$ 를 차지하였다(Figure 7$)$. 기타 의견으로는 시 술 후 추적 관찰 때 신경을 많이 써야 한다, 수술 시마다 부채꼴모 양 만들기가 번거롭고 불편하다, 헤르니아(hernia)수술에 사용하 는 메시처럼 실로 당기면 부채꼴이나 구형모양이 되는 다양한 사 이즈의 메시가 나오면 좋겠다라는 의견이 있었다.

\section{요약 및 제안}

전 세계적으로 가장 많은 메시 사용의 경험이 있는 한국의 유방 외과 의사들의 실제 메시 사용현황을 살펴본 결과, 다양한 적응증, 사용방법과 추적관찰방법을 가지고 실제 임상에 적용하고 있음을 알 수 있었다. 가격이 비싸다는 점과 합병증이 많다는 답변이 있었 지만, 수술 후 모양이 좋고 신속히 수행할 수 있다는 장점이 있었 으며, 메시 사용 경험이 없는 답변자를 포함한 많은 답변자들이 우

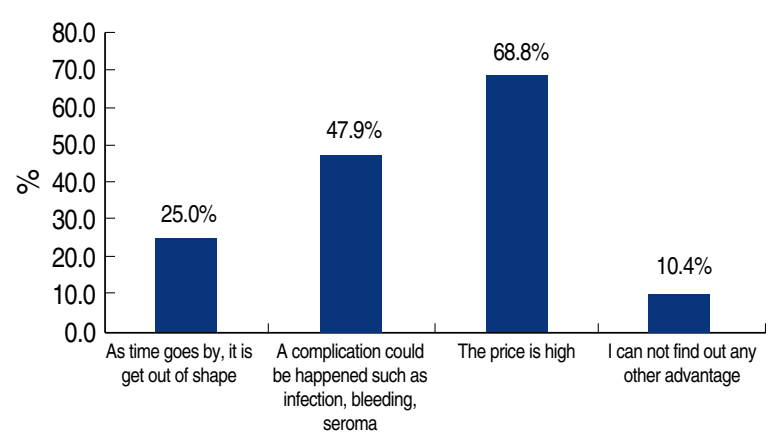

Figure 7. The disadvantage of absorbable mesh.

려했던 합병증인 감염률은 실제로는 약 $3.8 \%$ 로 나타나 좋은 표준 지침을 가진다면 많은 장점을 극대화할 수 있을 것으로 예상된다. 현재 한국유방암학회 유방외과술기연구회에서 메시 사용지침을 개 발하려고 하는 연구에 동참하실 의사를 묻는 질문에 $77.1 \%$ (n=37/ 48)가 동참할 의사가 있다고 답하였고, $20.8 \%$ ( $n=10 / 48)$ 가 구체 적인 연구계획이 나오면 재고하겠다고 답했다. 그러므로 유방수 술에서의 메시 사용의 안정성과 장점을 입증하기 위하여 앞서 언 급한 합병증과 관련된 중요 요인을 고려한 후, 수술 후의 환자와 수술자의 만족도와 종양학적 안정성을 객관적인 평가 도구로 입 증할 수 있는 전향적 임상연구(prospective randomized trial) 가 필요하다고 하겠다.

\section{감사의 글}

설문조사에 응해주신 선생님들께 감사의 말씀을 전합니다. (병 원명 가나다순, 존칭 생략): 강남성심병원 정봉화, 강남차병원 박 해린, 강북삼성병원 박용래, 염차경, 강원대병원 김양희, 건국대 병원 강현종, 경상대병원 문형곤, 계명대 동산병원 조지형, 고대 안암병원 배정원, 이은숙, 고려구로병원 우상욱, 관동대 명지병원 신혁재, 광명성애병원 최상용, 국립경찰병원 차진우, 국립암센터 김석원, 정소연, 단국대병원 장명철, 대구임재양외과 임재양, 대 구파티마병원 김상윤, 대전을지병원 최영진, 동아대병원 조세헌, 보라매병원 황기태, 부산백병원 김태현, 부천순천향대병원 임철 완, 분당서울대병원 김성원, 상계백병원 곽금희, 서울삼성병원 남 석진, 양정현, 이정언, 서울성모병원 송병주, 채병주, 서울아산병 원 손병호, 인천성모병원 오세정, 수원중앙병원 엄태익, 순천향 천안병원 김성용, 한선욱, 아주대병원 김구상, 정용식, 영남대병 원 강수환, 원광대병원 최운정, 원자력의학원 김현아, 노우철, 유 선외과의원 이은규, 인천길병원 박흥규, 인하대병원 김세중, 조영 업, 일산동국대병원 곽범석, 일산백병원 김재일, 전북대병원 윤현 조, 제일병원 강성수, 고승상, 천안충무병원 류진우, 포항세명기 독병원 서동권, 한림대성심병원 김이수, 화순전남대병원 윤정한. 


\section{참고문헌}

1. The Korean Breast Cancer Society. Nationwide Korean breast cancer data of 2004 using breast cancer registration program. J Breast Cancer 2006;9:151-61.

2. Ko SS, Korean Breast Cancer Society. Chronological changing patterns of clinical characteristics of Korean breast cancer patients during 10 years (1996-2006) using nationwide breast cancer registration on-line program: biannual update. J Surg Oncol 2008;98:318-23.

3. Fisher B, Bauer M, Margolese R, Poisson R, Redmond C, Fisher E. Five-year results of a randomized clinical trial comparing total mastectomy and segmental mastectomy with or without radiation in the treatment of breast cancer. N Engl J Med 1985;312:665-73.

4. Eom TI, Kim BS, Koo BY, Kim JW, Lim YA, Lee HH, et al. The use of a corrective procedure with vicryl mesh for oncoplastic surgery of the breast. J Breast Cancer 2009;12:36-40.

5. Clough KB, Lewis JS, Fitoussi A, Faucoult MC. Oncoplastic techniques allow extensive resection for breast-conserving therapy of breast carcinomas. Ann Surg 2003;237:26-4.

6. Ohuchi N, Harada Y, Ishida T. Breast conserving surgery for primary breast cancer: immediate volume replace using lateral tissue flap. Breast Cancer 1997:4:59-65.

7. Rietjens M, Urban CA, Rey PC, Mazzarol G, Maisonneuve P, Garusi $\mathrm{C}$, et al. Long-term oncological results of breast conservative treatment with oncoplastic surgery. Breast 2007;16:387-95.

8. Sanuki J, Fukuma E, Wadamori K, Higa K, Sakamoto N, Tsunoda Y. Volume replacement with polyglycolic acid mesh for correcting breast deformity after endoscopic conservative surgery. Clin Breast Cancer 2005;6:175.

9. Lee JH, Hong YI, Jeong JH, Lee JI, Lee JH, Moon HJ, et al. Volume replacement with polyglatin 910 mesh for breast reconstruction after endoscopy-assisted breast conserving surgery for treating early breast cancer: the early results. J Breast Cancer 2009;12:193-8. 